\title{
Above-knee amputation followed by femoral replantation: 21-year follow-up results after lower limb replantation
}

\author{
Femur replantasyonunun takip ettiği diz üstü ampütasyon: \\ Alt uzuv replantasyonu sonrası 21 yıllık takip sonuçları
}

\author{
Antal Renner, MD. PhD. DSc., ${ }^{1}$ Annamária Szentirmai, MD., ${ }^{1}$ Andrea Sántha, MD., ${ }^{1}$ Tamás Viola, MD., \\ Ferenc Gyárfás, MD., ${ }^{2}$ András Melly, MD., ${ }^{2}$ Péter Varga, MD., ${ }^{3}$ Tibor Retteghy, MD. ${ }^{3}$
}

\begin{abstract}
'Department of Hand and Microsurgery, Péterfy Hospital, Trauma Centre (former National Institute of Traumatology), Budapest, Hungary ${ }^{2}$ Department of Musculoskeletal Surgery, Péterfy Hospital, Trauma Centre (former National Institute of Traumatology), Budapest, Hungary ${ }^{3}$ Intensive Care Unit, Péterfy Hospital, Trauma Centre (former National Institute of Traumatology), Budapest, Hungary
\end{abstract}

\begin{abstract}
In this article, we report successful treatment of serious complications of replantation after traumatic mid-third femoral amputation. To the best of our knowledge, no similar case has been reported in the literature. A 38-year-old healthy male sustained a mid-third right traumatic femoral amputation. We performed replantation. Oliguria and anuria occurred and were treated successfully with hemofiltration and hemodialysis. Six years later, patient walked wearing orthopedic shoes and also protective sensibility recovered on the limb. Serious complications of proximal lower limb replantation can be treated successfully and the limb is saveable.
\end{abstract}

Keywords: Amputation; complications; lower extremity; replantation; traumatic.

Literature on lower limb replantation continues to lack uniformity. Primary amputation is performed because of potentially life threatening postoperative complications and availability of technically refined lower limb orthoses, furthermore, safety and cost reduction are also taken into consideration. ${ }^{[1]}$ After replantation at this level of the limb, when the decision was made based on several well known score systems, the replanted limb is usually amputated immediately after the appearance of the first symptoms of complications. ${ }^{[2-4]}$ According to some authors, heterotopic replantation of the lower limb is
$\ddot{O} Z$

$\mathrm{Bu}$ yazıda, femurun orta üçte birinde travmatik ampütasyon sonrası ciddi replantasyon komplikasyonlarının başarılı tedavisi sunuldu. Bildiğimiz kadarıyla, literatürde benzeri bir olgu bildirilmemiştir. Otuz sekiz yaşında sağlıklı bir erkek sağ femurun orta üçte birinde travmatik ampütasyona maruz kaldı. Replantasyon uygulandı. Oligüri ve anüri gelişti ve hemofiltrasyon ve hemodiyaliz ile başarıyla tedavi edildi. Altı yıl sonra, hasta ortopedik ayakkabı giyerek yürüdü ve uzuvda koruyucu sensibilite düzeldi. Proksimal alt uzuv replantasyonunun ciddi komplikasyonları başarıyla tedavi edilebilir ve uzuv kurtarılabilir.

Anahtar sözcükler: Ampütasyon; komplikasyonlar; alt ekstremite; replantasyon; travmatik.

indicated only in children ${ }^{[5,6]}$ and in case of bilateral amputation. ${ }^{[7,8]}$

In our case, we performed the replantation in 1986, when microsurgery was in a very early phase of development, furthermore, no score systems predicting the expected success of the replantation existed [such as Mangled Extremity Score (MESS), Limb Salvage Index (LSI), Predictive Salvage Index (PSI), Nerve injury- Ischemia- Soft tissue injurySkeletal injury- Shock- Age of patient (NISSSA), Hannover Fracture Scale (HFC)-97 version, Battiston

- Received: September 01, 2015 Accepted: November 24, 2015

- Correspondence: Antal Renner, MD. PhD. DSc. Department of Hand and Microsurgery, Péterfy Hospital, Trauma Centre (former National Institute of Traumatology), Budapest, Hungary. Tel: +36-1-299 7718 Fax: +36-1-33 43584 e-mail: antalrenner@t-online.hu 
new scoring system] and no devices were available for routine use in the treatment of life threatening complications (hemodialysis).

\section{CASE REPORT}

A 38-year-old man with strong body construction was transferred by ambulance to our hospital on the 15 March 1986 at 08:04 am. While he was working as a fork-lift trailer driver, sitting on the seat with his thigh in a horizontal position, an iron plate weighing approximately one ton fell onto his thigh from a height of several meters at 07:45 and amputated his lower limb 18 centimeters above the knee joint. The amputated part of the limb was connected to the thigh by a severely damaged, perforated, palm-sized dorsal skin flap (Figure 1a). The staff of the MICU (Mobile Intensive Care Unit) performed the patient transfer in a professional manner, his vital parameters were stable. At our hospital, we continued to stabilize of his condition immediately. A written informed consent was obtained from the patient. There were no diseases in his general medical history, which could have precluded a major surgical intervention in order to save his limb. Laboratory investigations, X-rays (Figure 1b), Doppler sonography and physical examinations were performed immediately. All circumstances were optimal at the hospital, thus we started the replantation after getting his informed consent. Team number 1 (responsible for replantation) prepared the amputated part of the limb according to professional rules, while team number 2 (trauma surgeons) prepared the proximal stump of the thigh for replantation. The stump of the femoral artery could be found at the entrance of the adductor channel and the stumps of the femoral and saphenous veins were at the same height. We immediately introduced a heparin infusion into the stump of the femoral artery. The skin of the thigh was mangled on the lateral side with a defect, thus excision was performed. The stump of the amputated part of the limb was shortened 2 centimeters and the thigh (femur) 3 centimeters. After a decompression plate plate osteosynthesis was performed according to AO (Arbeitsgemeinschaft für Osteosynthesefragen) principles (Figure 2a), we performed an end-toend anastomosis on the femoral artery. Excellent retrograde bleeding could be observed from the stumps of major the veins after release of arterial tourniquet. The duration of warm ischemia was five hours (12:45 o'clock). This was followed by the suture of femoral vein and vena saphena magna. After resection of the macroscopically damaged parts of the vastus medialis, rectus femoris and vastus lateralis muscles, we adapted the fibres of the remaining muscle with sutures. The compartments of the lower leg muscles were split longitudinally in order to prevent compartment syndrome. We performed an epi- and perineural suture of the torn sciatic nerve and covered the skin defects with Paul Hartmann AG, Heidenheim, Germany Syspur-derm ${ }^{\circledR}$ skin- substitute. We inserted silicone drains into all wounds. The blood circulation of the limb was excellent after surgery at 1:45 pm, the limb warmed up, its capillary circulation was perfect and the dorsal pedal pulse was very well palpable. The patient was transferred to the intensive care unit, where he spent 37 days. His treatment was continued from 21 April 1986 to 27 July 1986 (from the $37^{\text {th }}$ postoperative day to the $133^{\text {rd }}$ ) at our Septic Department. Professional physiotherapy was performed during this period of time: walking exercises were begun gradually, at the beginning with crutches and later on with a walking
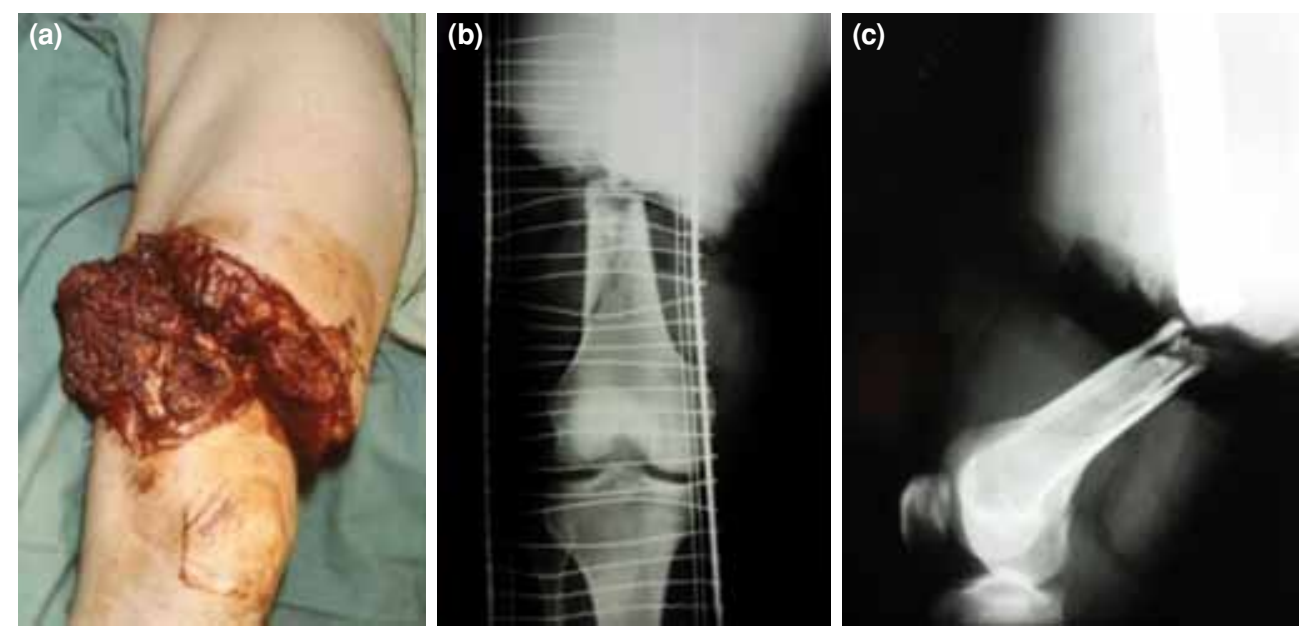

Figure 1. (a) The amputated limb upon admission to our hospital. (b) Preoperative anteroposterior and lateral $\mathrm{X}$-rays. 

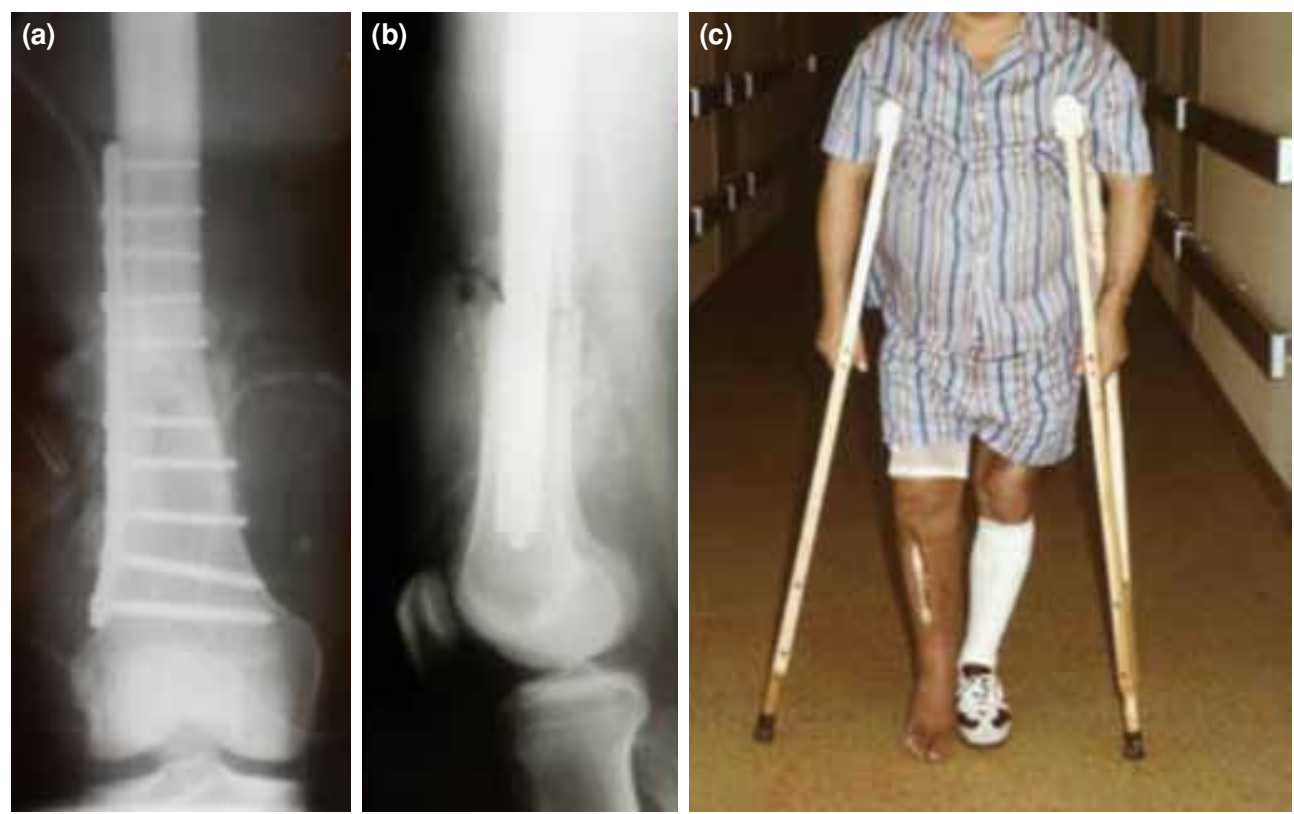

Figure 2. (a) Primary osteosynthesis: postoperative anteroposterior and lateral X-rays. (b) Prior to discharge, mobilized with crutches.

frame (Figure 2b). He was discharged on 27 July 1986; he used crutches (Figure 3) at this time and he was followed-up on a regular basis. At our department, we constantly perform scientific investigation of ischemic-reperfusion tissue damages; thus, at the time of the suture of the femoral artery, we took samples for histological and electron microscopic investigations from the medial vastus muscle and from the anterior tibial muscle and the gastrocnemius muscle on the third, $15^{\text {th }}$ and $23^{\text {rd }}$ days after replantation. As a result of our investigations we concluded that muscle necrosis appears in a focal manner after replantation, muscle regeneration begins as early as the third to fifth day, but muscle regeneration is impaired by neurogenic muscle damage developing in the meantime. We also stated that blood circulation of the replanted limb significantly differs from that of the intact limb and this difference of blood circulation is demonstrable even months after replantation and may play a role in reservation of tissue damages.
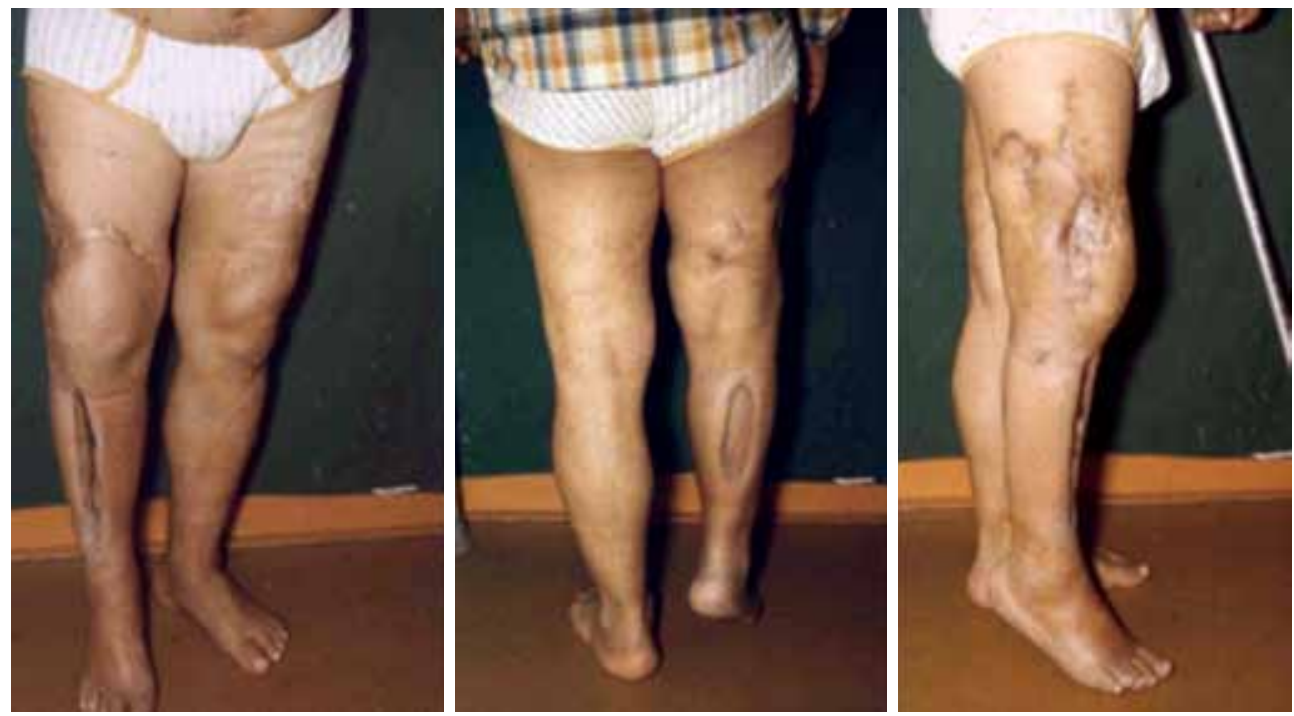

Figure 3. One year after replantation. 

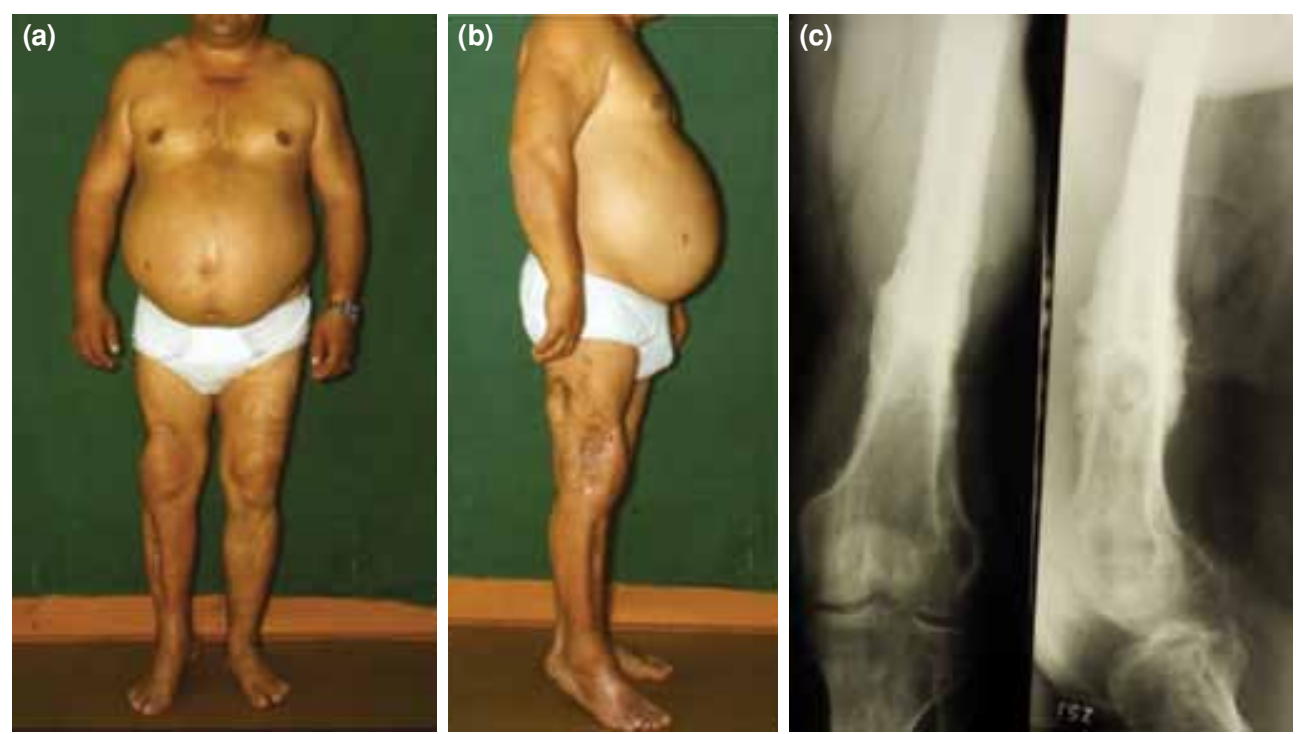

Figure 4. (a) and (b) six years after replantation. He gained a considerable amount of weight and wears a heel lift insertion in his shoe (c) radiograph of the femur with bony consolidation.

Six years after surgery, he was able to walk without any walking aid in an orthopedic shoe with elevated heel and also protective sensibility was developed in this limb (Figure 4). He was completely satisfied with the surgical result; the orthopedic shoe was a good choice for him.

Type 2 diabetes developed four years later; unfortunately, the patient was unable to properly follow the diet and prescribed medication. He consumed too much alcohol and became significantly obese. The big toe of the replanted limb developed partial gangrene due to diabetic arteriopathy six years after replantation, which healed after surgical excision in our Septic Department. An arteriography
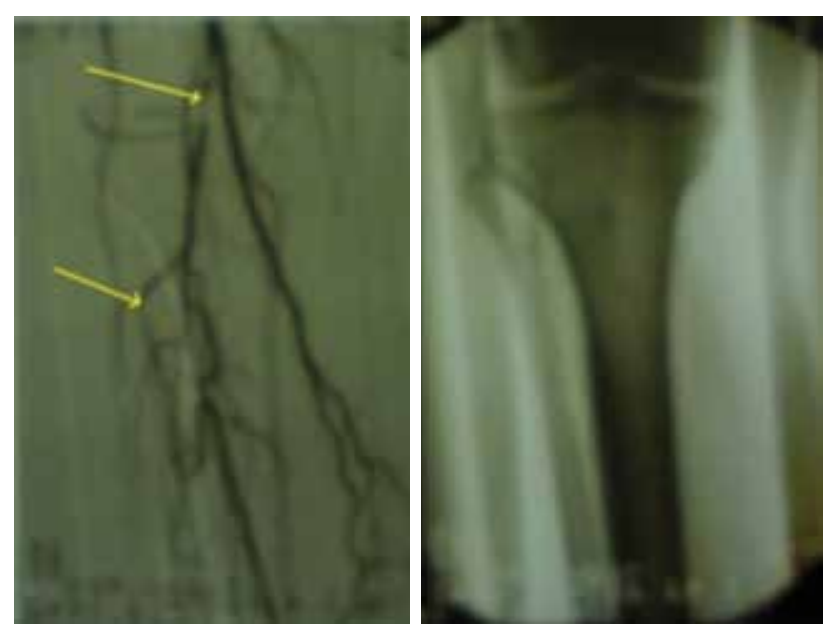

Figure 5. Angiographic images (upper arrow: art. poplitea; lower arrow: art. tibialis anterior). of the replanted limb was performed in order to assess the severity of the diabetic arteriopathy on 26 June 1992 (Figure 5) this was followed by a successful percutaneous transluminal angioplasty (PTA). The patient changed his residence and did not present himself for further follow-up visits. We planned to publish a retrospective, comprehensive study on the long-term results of the patients after replantation at the end of the XX. Century. We wrote letters including questionnaires to our former patients. In this case his wife answered us. She wrote, His thigh was amputated in the proximal third due to diabetic arteriopathy at the local surgical department in 2002, 16 years after replantation. He was fitted with a prosthetic device, but he didn't use it, he walked with crutches instead. He died as a consequence of myocardial infarction in 2007, 21 years after replantation.

\section{DISCUSSION}

There are reports in the current literature about cases, when more amputated limbs of the same patient were successfully replanted, ${ }^{[0]}$ the soft tissue defect was replaced with a free flap at the time of replantation ${ }^{[10]}$ or the amputated part of the limb was temporarily replanted in a more proximal position. In the majority of the publications the authors do not distinguish between reported cases of distal and proximal lower limb amputations/replantations. They usually evaluate these cases as a homogenous group, ${ }^{[11]}$ albeit physiological factors influencing the outcome of replantations are more advantageous in case of lower leg replantations ${ }^{[12]}$ than those of 
replantations performed above the knee and in the mid-third of the thigh.

Despite the development of medicine and microsurgical techniques, there are only a few cases reported in the literature, when primary replantation was performed after proximal lower limb amputations, taking into account the potential complications requiring treatment or even the unsuccessfulness of the replantation..$^{[13]}$

There has been an enormous development in microsurgical technique, intensive care and medication options since the treatment of our presented patient, in the last three decades. The same applies to the variety of up-to-date prosthetic devices, which are now suitable for sporting and leisure time activities and facilitate the activities of daily living of the patients with amputated limbs.

As a result of scientific investigation of traumainduced physiological processes, different score systems are available, which make the surgical decision easier immediately after injury. We firmly believe that many more proximal lower limb replantations are performed than published in the literature, because in case of complications, amputation is performed.

In conclusion, with this case report we would like to encourage our colleagues: complications of proximal lower limb replantation, serious renal dysfunction can be treated successfully and the limb can be salvageable, if the treatment is performed by an enthusiastic, determined and cooperative interdisciplinary team (trauma surgeon, hand surgeon experienced in microsurgery and plastic surgery, intensive therapist) under optimal circumstances.

\section{Declaration of conflicting interests}

The authors declared no conflicts of interest with respect to the authorship and/or publication of this article.

\section{Funding}

The authors received no financial support for the research and/or authorship of this article.

\section{REFERENCES}

1. Märdian S, Schaser KD, Wichlas F, Jakobs C, Kraphol B, Schwabe P. Lower limb salvage: indication and decision making for replantation, revascularisation and amputation. Acta Chir Orthop Traumatol Cech 2014;81:9-21.

2. Battiston B, Tos P, Pontini I, Ferrero S. Lower limb replantations: indications and a new scoring system. Microsurgery 2002;22:187-92.

3. Fufa DT, Lin CH, Lin YT, Hsu CC, Lin CH. Survival and secondary surgery following lower extremity replantation. J Reconstr Microsurg 2014;30:419-26.

4. Gao YS, Ai ZS, Zhang CQ, Jin DX, Chen SB, Zhu Y, et al. Replantation of above-knee amputation: a surviving but dysfunctional case needing secondary amputation. J Reconstr Microsurg 2010;26:631-5.

5. Mamakos MS. Lower extremity replantation-two and a half-year follow-up. Ann Plast Surg 1982;8:305-9.

6. Masuda K, Usui M, Ishii S. A 17-year follow-up of replantation of a completely amputated leg in a child: case report. J Reconstr Microsurg 1995;11:89-92.

7. Fang CL, Yang CS, Tang HC, Changchien CH, Lai YY. Successful replantation of amputated bilateral lower limbs. Plast Reconstr Surg 2012;129:215-7.

8. Fang J, Li H, Dou H, Chen J, Xu A, Liu W, et al. Crossover replantation after bilateral traumatic lower limb amputations: a case report. J Med Case Rep 2012;6:218.

9. Pei GX, Kunde L, Chuwen C, Dengshong Z, Fuyi W, Songto $\mathrm{W}$, et al. Replantation of four severed limbs in one patient. Injury 1997;28:73-6.

10. Akoz T, Yildirim S, Akan M, Gideroglu K, Avci G, Cakir B. Can indications for lower limb replantation and revascularization be expanded with simultaneous free-flap transfer for limb salvage? J Reconstr Microsurg 2004;20:621-9.

11. Hierner R, Berger AK, Frederix PR. Lower leg replantation-decision-making, treatment, and long-term results. Microsurgery 2007;27:398-410.

12. Yüksel F, Karacaoğlu E, Ulkür E, Güler MM. Replantation of an avulsive amputation of a foot after recovering the foot from the sea. Plast Reconstr Surg 2000;105:1435-7.

13. Vilkki S, Mustonen P, Huopio J. Replantation of amputated leg. First case in Finland, how is the patient doing 25 years later?. Duodecim 2005;121:617-21. 